\title{
Limnological characteristics and planktonic diversity of five tropical upland lakes from Brazilian Amazon
}

\author{
Prafulla K. Sahoo ${ }^{1, *}$, José T.F. Guimarães ${ }^{1}$, Pedro W.M. Souza-filho ${ }^{1}$, Reinaldo Luiz Bozelli ${ }^{2}$, \\ Luciana Rabelo de Araujo², Rafaella de Souza Menezes ${ }^{1}$, Paloma Marinho Lopes ${ }^{2}$, \\ Marcio S. da Silva ${ }^{1}$, Tarcísio M. Rodrigues ${ }^{3}$, Marlene F. da $\operatorname{Costa}^{3}$ and Roberto Dall'Agnol ${ }^{1}$ \\ ${ }^{1}$ Instituto Tecnológico Vale, Rua Boaventura da Silva, Belém, Pará, Brazil \\ ${ }^{2}$ Laboratório de Limnologia, Departamento de Ecologia, Instituto de Biologia, Universidade Federal do Rio de Janeiro, CCS, Cidade \\ Universitária, Rio de Janeiro, Brazil \\ ${ }^{3}$ Gerência de Meio Ambiente - Minas de Carajás, Departamento de Ferrosos Norte, Estrada Raymundo Mascarenhas, S/N Mina deN4, \\ 68516 000, Parauapebas, Pará, Brazil
}

Received: 15 June 2017; Accepted: 16 October 2017

\begin{abstract}
A limnological investigation involving physical, chemical and biological aspects was undertaken in five tropical upland lakes (Violão - Vl, Amendoim - Am, and Três Irmãs - TI1, TI2 and TI3) from Serra dos Carajás, Brazil. Results show that these lakes are shallow, weakly stratified, and of polymictic type. These characteristics may have caused vertical mixing of limnological parameters. Seasonal changes were minor for most parameters, except for chlorophyll- $a(\mathrm{Chl}-a)$ and cyanobacteria, which also showed considerable variation between lakes. In general, waters of these lakes were mostly acidic in nature (avg. $\mathrm{pH} 4.9-5.9$ ), with high total Fe (up to $1.52 \mathrm{mg} / \mathrm{L}$ ) and low electrolytic conductivity (avg. 8.13-14 $\mu \mathrm{S} / \mathrm{cm}$ ) and total phosphorus (TP) (avg. 10-35.5 $\mu \mathrm{g} / \mathrm{L}$ ). Although the water bodies have good quality and classified as class I and II types according to CONAMA Resolution No. 357/05, trophic state index (TSI) varies from ultra-oligotrophic to eutrophic state, with higher trophic state observed for V1, TI1 and TI2. Limnological characteristics of these lakes is highly influenced by lithological and morphological parameters. Principal component analysis (PCA) reveals that Chl- $a$ and cyanobacteria are not solely influenced by TP and lower concentrations of all these parameters in Am lake are probably due to specificities of its catchment lithology. Phytoplankton taxa in the lakes are characterized by small chroococcales groups and desmids together with filamentous algae, more commonly observed in the dry season. The zooplankton community in the lakes is mainly dominated by rotifers, followed by cladocerans and copepods. Regarding species richness, zooplankton was highest in Vl, while phytoplankton is highest in TI1, and this aspect is most likely related to lake water levels.
\end{abstract}

Keywords: limnology / water quality / phytoplankton / zooplankton / upland lakes / Serra dos Carajás

\section{Introduction}

The limnology of tropical lakes has become a high priority and draws major attention in the contemporary limnological research. This is particularly true for high mountain tropical lakes which are important freshwater ecosystems and likely the most comparable ecosystems across the world (Gunkel, 2000; Sahoo et al., 2016). A comparison between lakes of tropical and temperate areas indicates that their limnology differs significantly due to variations in physical and chemical characteristics of waters such as temperature, thermal stratification, lake levels,

\footnotetext{
*Corresponding author: prafulla.sahoo@itv.org
}

light and nutrient availability (Lewis, 1987; Gunkel, 2000; Catalan and Rondón, 2016). These factors largely govern trophic state, phytoplankton assemblage as well as the planktonic growth of lakes (Reynolds et al., 2002; Molisani et al., 2010). Plankton is a sensitive and good indicator of changes in aquatic environment due to its rapid response to short time intervals, especially in the reproductive processes (Frisch et al., 2012, Silva et al., 2013). Thus, knowledge of the structure and functioning of these biological communities, and their interaction with the environment become essential for understanding the dynamic of these lakes (Huszar and Reynolds, 1997; Lopes et al., 2011, 2014), as well as help in detecting any possible alteration in water quality (Diehl et al., 2002; Chellappa et al., 2009a; Molisani et al., 2010). 

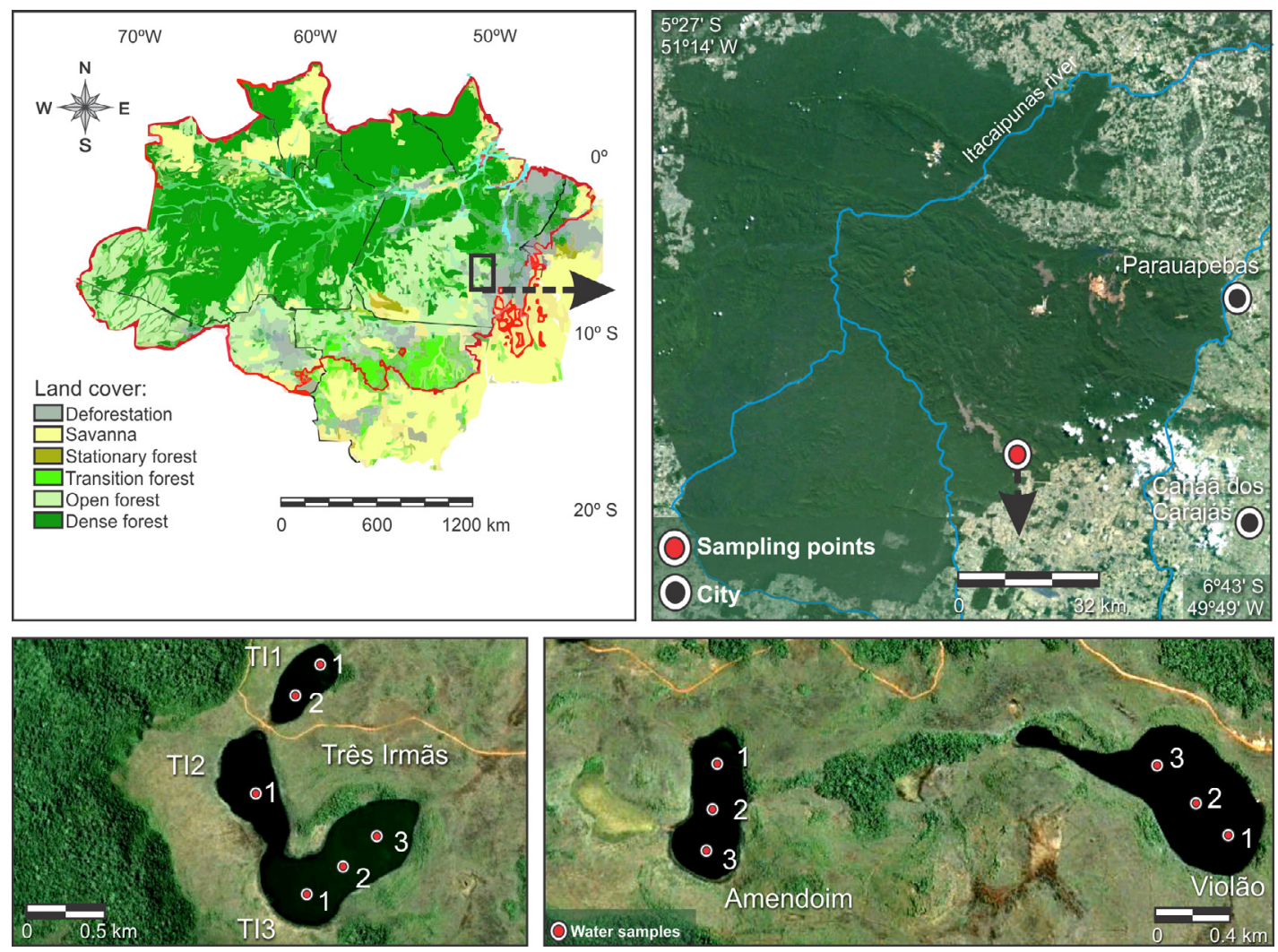

Fig. 1. Location map of the study area and sampling points of Violão, Amendoim, Três Irmãs lakes from Serra dos Carajás, PA, Brazil.

Tropical lakes serve as a crucial life support system by providing water for drinking, irrigation, and recreation opportunities such as fishing, boating and wildlife conservation. However, these lakes have been facing different challenges, such as eutrophication by nitrogen and phosphorus compounds, acidification and climate changes, which are the major causes of water quality degradation (Livingstone, 2003; Osborne, 2004; Hundey et al., 2016; Catalan and Rondón, 2016). Effective monitoring of these lakes and their classification as per scientific norms and environmental laws are important aspects of lake's survey usable to establish freshwater's condition and long-term trends for effective management with the aim of achieving good water quality (Carlson, 1977; Burden and Malone, 1987; Buraschi et al., 2005; Pasztaleniec and Poniewozik, 2010). A wide view of limnological classification has been proposed world-wide based on the morphology, physical, chemical and biological characteristics of waters (Häkanson and Jansson, 1983; Burden and Malone, 1987; Busch and Sly, 1992; Margaritora et al., 2003; Rowan et al., 2006; Skowron, 2009; Wang et al., 2014). However, these efforts are still incipient for Brazilian lakes and missing for upland lakes of Amazonia. The Carajás province in Amazonia has some of the largest iron deposits of the world (Paradella et al., 2015). In it, several upland lakes, which are hydrologically restricted and located at $>650 \mathrm{~m}$ above mean sea level (amsl), formed over laterite crust by structural and degradation process (Maurity and Kotschoubey, 1995). These lakes are valuable sites for scientific research and for different water uses, besides providing habitat for flora and fauna and plankton species (Sahoo et al., 2016; Lopes et al., 2011; Guimarães et al., 2017). However, though a few reports are available on hydro-biogeochemical characteristics (Sahoo et al., 2016) and on plankton diversity (Lopes et al., 2011), there is lack of data on the detailed limnological work of these lakes.

In this backdrop, the present survey was undertaken between 2013 and 2016 on five upland lakes of the Serra Sul dos Carajás based on the physical, chemical and microbiological characterization in waters, as well as plankton assemblages, which were monitored between 2011 and 2013. The aim of this study was to deepen the knowledge of the limnology of these lakes and to classify them based on their limnological characteristics.

\section{Materials and methods}

\subsection{Study area and geology}

Violão (Vl), Amendoim (Am) and Três Irmãs (TI1, TI2, and TI3) lakes (coordinate: $6.4^{\circ} \mathrm{S}, 50.4^{\circ} \mathrm{W}$ ) are located in a plateau in the Serra Sul dos Carajás in SE Amazonia, Brazil around (Fig. 1). These lakes are hydrologically restricted and developed on a lateritic crust, which is covered by montane savanna vegetation and surrounded by Amazon rainforest (Fig. 1). Open forest and small patches of high-and-low forest can also be observed in central portions of the plateau over degraded crusts (Golder, 2010; Guimarães et al., 2014). These laterites are extensively developed over banded iron formations (Silva et al., 2009; Morais et al., 2011).

Among these lakes, surficial water connection was observed in the TI lake system, but not in the case of Am and Vl lakes. Caves only occur in the catchment of Vl, with 
concentrated or dispersed occurrence of guano. Bird guano was also observed along the catchment of Vl. These guano occurrences and altered mafic rocks, which are found only in the northwestern portion of V1 Lake catchment, are potential source of phosphorous for Vl lake (Sahoo et al., 2015). In contrast, caves and mafic rock outcrops were not observed around the catchment of the Am and, in results, $\mathrm{P}$ contents are low compared to Vl. Regarding Três Irmãs lake system, in the catchment of TI1 and TI3 there are locally thick soils related to iron-aluminous laterite (probably originated from metavolcanic rocks) whereas similar soils have not been noticed in the catchment of TI2. A tropical monsoon climate (Alvares et al., 2014), with a mean annual temperature of around $26^{\circ} \mathrm{C}$ and total annual rainfall ranges from 1800 to $2300 \mathrm{~mm}$, with an average of around $1550 \mathrm{~mm}$ during the rainy season (November-May) and of ca. $350 \mathrm{~mm}$ during the "dry" season (June-October) (Moraes et al., 2005), is observed in the studied region.

\subsection{Sampling and analytical method}

\subsubsection{Limnological parameters}

For limnological study, water samples were collected biannually in both rainy and dry seasons between 2013 and 2016. The monitoring points in each lake were chosen following their longitudinal profiles based on the bathymetric map and drainage patterns, which are presented in Figure 1. At each sampling point, three depths layered sampling (surface, middle and bottom of lake) was performed, except for TI2 (only surface) and TI1 (surface and bottom) because of their shallower water depth. Van Dorn water sampler was used to collect sample and then stored in HDPE and glass bottles following ABNT (1987) and SMEWW (2005). The inorganic, organic and bacteriological parameters were analyzed by using the SGS Geosol and Bureau Veritas analytical facilities following EPA (2004), SMEWW (2005) and CETESB (2006) guidelines. An overall precision, expressed as relative percent differences $(\mathrm{RPD}=100 \times($ duplicate $1-$ duplicate 2$) /($ average of two duplicates), was obtained below $10 \%$ for all samples. Vertical profiles (at every meter from surface to the bottom) of water temperature, $\mathrm{pH}$, dissolved oxygen (DO), electrical conductivity (EC), total dissolved solid (TDS) were measured in situ using Horiba W-20XD multi sensor probe. Water transparency was measured with a Secchi disc (Secchi depth: $\left.Z_{\text {Secchi }}\right)$. Water quality classification was made using the Brazilian environmental regulation, National Environmental Council (CONAMA) Resolution No. 357/05 (Brasil, 2005). This classification ranges from class 1 to class 4 based on their water use and human consumption. The morphometric analysis of the lakes was conducted using Surfer software 13, Golden Software Incorporation, 2015.

\subsubsection{Calculation of Water Quality Index (WQI)}

Water Quality Index (WQI) was calculated following the equation established by Brown et al. (1970), using the weighted scores of a set of nine specific variables: temperature, $\mathrm{pH}, \mathrm{DO}$, biochemical oxygen demand (BOD), thermotolerant coliforms, dissolved inorganic nitrogen, total phosphorus (TP), total solids and turbidity. Each parameter is weighted by a value between 0 and 1 and the sum of all weights is 1 (CETESB, 2004-2006). WQI classification is as follows: Excellent: $79<\mathrm{WQI} \leq 100$; Good: $51<\mathrm{WQI} \leq 79$; Regular: $36<\mathrm{WQI} \leq 51$; Bad: $19<\mathrm{WQI} \leq 36$; Very bad: $\mathrm{WQI} \leq 19$.

\subsubsection{Calculation of Trophic State Index (TSI)}

Trophic State Index (TSI) of the lakes was obtained by using the most recent modified Carlson Index, proposed by Lamparelli (2004), which has been widely considered as the most accurate and suitable method for the classification of the trophic state of trophic/subtrophic reservoirs (Molisani et al., 2010). This index is based on three key variables, such as Chlorophyll- $a(\mathrm{Chl}-a)$, Secchi depth $\left(Z_{\text {secchi }}\right)$, and TP. TSI is calculated based on the average concentrations of these patameters in each sampling period. The classification classes as follows (Molisani et al., 2010)): TSI $\leq 47$, Ultra-oligotrophic; $47<\mathrm{TSI} \leq 52$, Oligotrophic; $52<\mathrm{TSI} \leq 59$, Mesotrophic; $\quad 59<$ TSI $\leq 63, \quad$ Eutrophic; $\quad 63<\mathrm{TSI} \leq 67$, Supereutrophic; and TSI $>67$, Hyperutrophic.

\subsection{Plankton community}

The phytoplankton and zooplankton communities were sampled from the dry season of 2011 to the rainy season of 2013 , in a total of four samplings. The zooplankton community was collected through vertical hauls with a $50 \mu \mathrm{m}$ plankton net and immediately preserved in a $4 \%$ formalin solution. In the laboratory, the individuals were identified to the lowest possible taxonomic level, based on Koste (1978) and ElmoorLoureiro (1997). For abundant species in each sample, three subsamples were counted in either a Sedgewick - Rafter cell under a microscope (for rotifers and nauplii) or in open chambers under a stereomicroscope (for cladocerans, copepodites, adult copepods). In each subsample at least 100 individuals were quantified. Additionally, the entire content of the samples was checked to identify species with low abundances. The phytoplankton community was collected directly in the lakes by immersing flasks of $100 \mathrm{~mL}$ below the surface of the water and immediately preserved in a Lugol's iodine solution. In the laboratory, the individuals were enumerated in random fields using the settling technique (Utermöhl, 1958). Individuals (cells, colonies and filaments) were counted, whenever possible, to reach 100 organisms of the most frequent species (Lund et al., 1958).

\subsubsection{Statistical analysis}

Statistical analysis such as principal component analysis (PCA) was used to evaluate the similarity between lakes and the main factors controlling water quality in relation to the environmental factors such as temperature, TP, Chl- $a, \mathrm{NH}_{4}-\mathrm{N}$, $\mathrm{NO}_{3}$, Escherichia coli, total coliform and cyanobacteria. This was carried out separately for rainy and dry seasons in all samples on raw data using the free statistical software $R(R$ Core Team, 2012). The Non-Metric Multidimensional Scaling based on Bray Curtis (for abundance data) and Jaccard's (for presence and absence data) Dissimilarity Index, was used to display the phyto and zooplankton communities structure. 


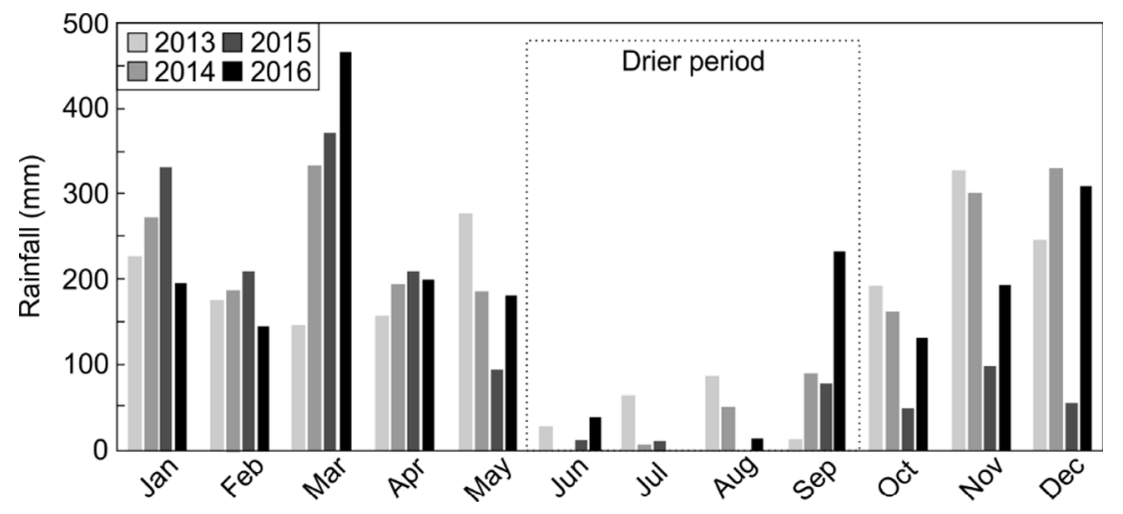

Fig. 2. Rainfall and temperature pattern in the study area for 2013-2016.

Table 1. Morphometric features of Carajás lakes according to the water frame work directive (WFD, Buraschi et al., 2005).

\begin{tabular}{lllllll}
\hline Lakes & Altitude $(\mathrm{m})$ & Classification & Mean depth $(\mathrm{m})$ & Classification & Surface area $\left(\mathrm{km}^{2}\right)$ & Classification \\
\hline V1 & 723.3 & Mid-altitude & 7.42 & Shallow & 0.273 & Very small \\
Am & 700.5 & Mid-altitude & 5.2 & Shallow & 0.126 & Very small \\
TI1 & 706 & Mid-altitude & 2.11 & Very shallow & 0.075 & Very small \\
TI2 & 698 & Mid-altitude & 1.2 & Very shallow & 0.116 & Very small \\
TI3 & 695.3 & Mid-altitude & 7.02 & Shallow & 0.252 & Very small \\
\hline
\end{tabular}

Morphometric features (Buraschi et al., 2005):

Altitude: high: $>800 \mathrm{~m}$; mid-altitude: $200-800 \mathrm{~m}$; lowland: $<200 \mathrm{~m}$.

Depth (mean depth): very shallow: $<3 \mathrm{~m}$; shallow: $3-15 \mathrm{~m}$; deep: $>15 \mathrm{~m}$.

Size (surface area): very small: $0-1 \mathrm{~km}^{2}$; small: $1-10 \mathrm{~km}^{2}$; very large: $>100 \mathrm{~km}^{2}$.

\section{Results}

\subsection{Hydro-climatic variables}

The monthly rainfall between 2013 and 2016 (Fig. 2) indicates a drier period from June to September with a total rainfall varying from 100 to $248 \mathrm{~mm}$. The wetter period extends from October to May with a total rainfall from 1415 to $1970 \mathrm{~mm}$. Regarding total annual rainfall, 2014 and 2015 were the wettest $(2118 \mathrm{~mm})$ and driest $(1515 \mathrm{~mm})$ years, respectively. The minimum and maximum air temperature registered from 2013 to 2016 were 17 and $35^{\circ} \mathrm{C}$, respectively.

\subsection{Morphometry}

According to the EU Water Frame Work Directive (WFD) adopted in 2000, the morphometric parameters used in the classification of lakes may be related to altitude, mean depth and surface area (Tab. 1). Based on this, the studied lakes of Carajás (located between 695 and $723 \mathrm{~m}$ amsl) fall into midaltitude category (Tab. 1). The surface area of lakes varies between 0.075 and $0.27 \mathrm{~km}^{2}$, which classified them into very small type. According to the morphometric classification of lakes imposed by the WFD (Buraschi et al., 2005), the depth of the lakes was considered as shallow for Vl (7.4 m), Am (5.2 m) and TI3 $(7.02 \mathrm{~m})$, and very shallow for TI1 and TI2 (Tab. 1), since their mean depth values were within the range from 3 to $15 \mathrm{~m}$ and $<3 \mathrm{~m}$, respectively.

\subsection{Limnological variables and classification}

The range and average concentrations of various limnological parameters within seasonal changes are as shown in Table 2. The vertical temperature profile and some selective parameters based on their epi- and hypolimnetic measurements in the studied lakes are presented in Figures 3 and 4, respectively. The average water temperature shows little variation between the dry $\left(25.73-30.1^{\circ} \mathrm{C}\right)$ and rainy season $\left(26.5-29.75^{\circ} \mathrm{C}\right)$ and comparatively higher temperature was noted for TI1, and TI2. The vertical temperature profile (Fig. 3) shows moderate decrease towards bottom in both rainy and dry periods for $\mathrm{Vl}$, and a slight decrease in the rainy season for Am and T13 lakes. TI1 showed decrease of temperature at bottom, but this is not the case for TI2, although both lakes are shallow ( $\sim 2 \mathrm{~m}$, mean depth). The temperature difference between the surface and bottom water of $\mathrm{Vl}$ varied from 0.57 to $2.8^{\circ} \mathrm{C}$, while in Am, TI1, TI2 and TI3 varied from 0.03 to $2{ }^{\circ} \mathrm{C}$ (Fig. 3). According to the classification based on lakes stratification and mixing characteristics (Hutchinson and Löffler, 1956; Häkanson and Jansson, 1983), most of the studied lakes can be classified as polymictic lakes. DO concentrations in the lakes fluctuated from 6.1 to $13.3 \mathrm{mg} / \mathrm{L}$ in the rainy period and $5.2-$ $10.5 \mathrm{mg} / \mathrm{L}$ in the dry period; higher concentrations were found in TI2 lake. Along the depth profile, DO concentration slowly decreases towards the bottom and in some cases the concentration was uniform. Although, DO content was higher at the surface than bottom (Fig. 4), the percentage of DO saturation remained at $80-140 \%$ throughout the entire water 


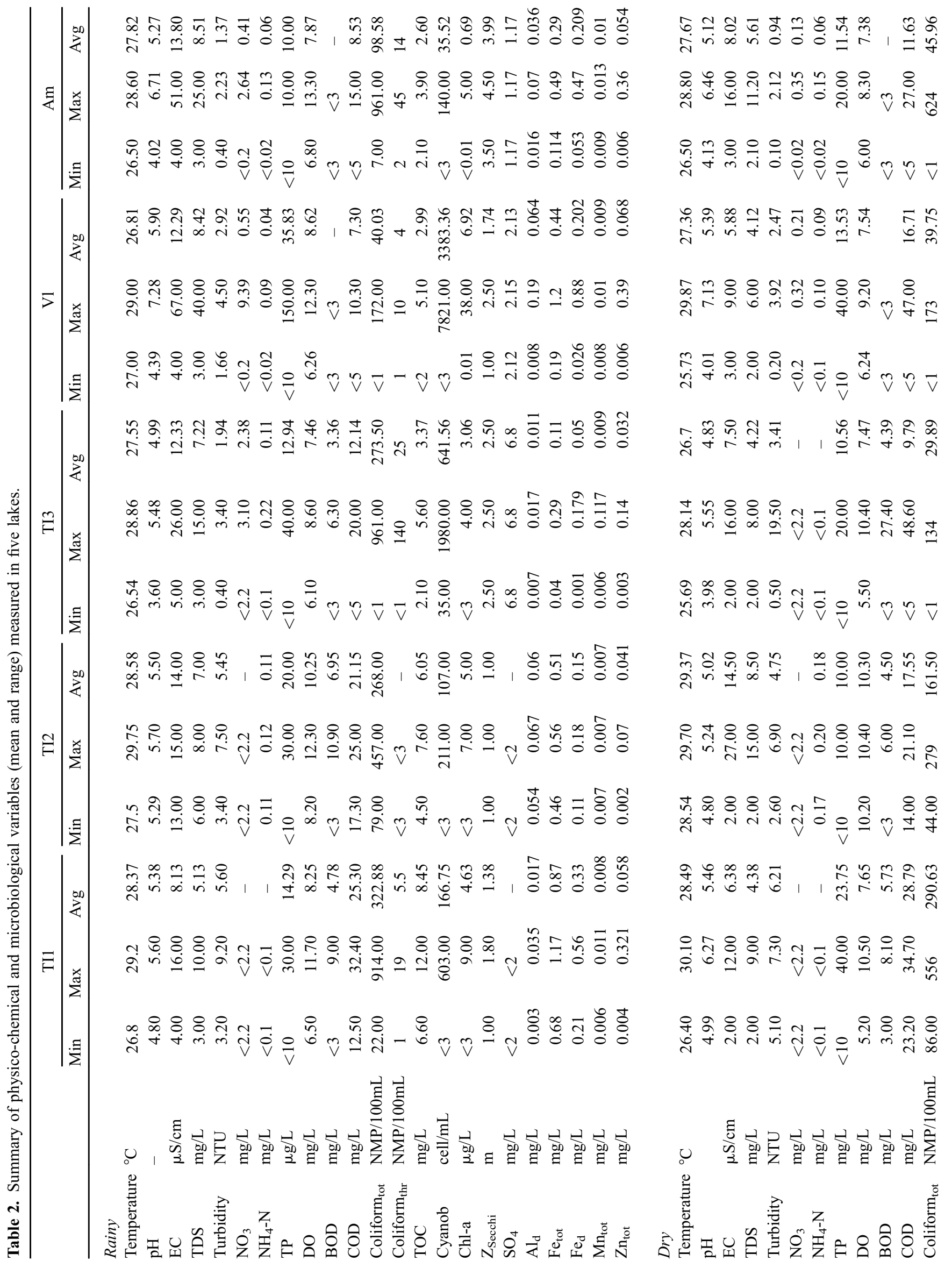




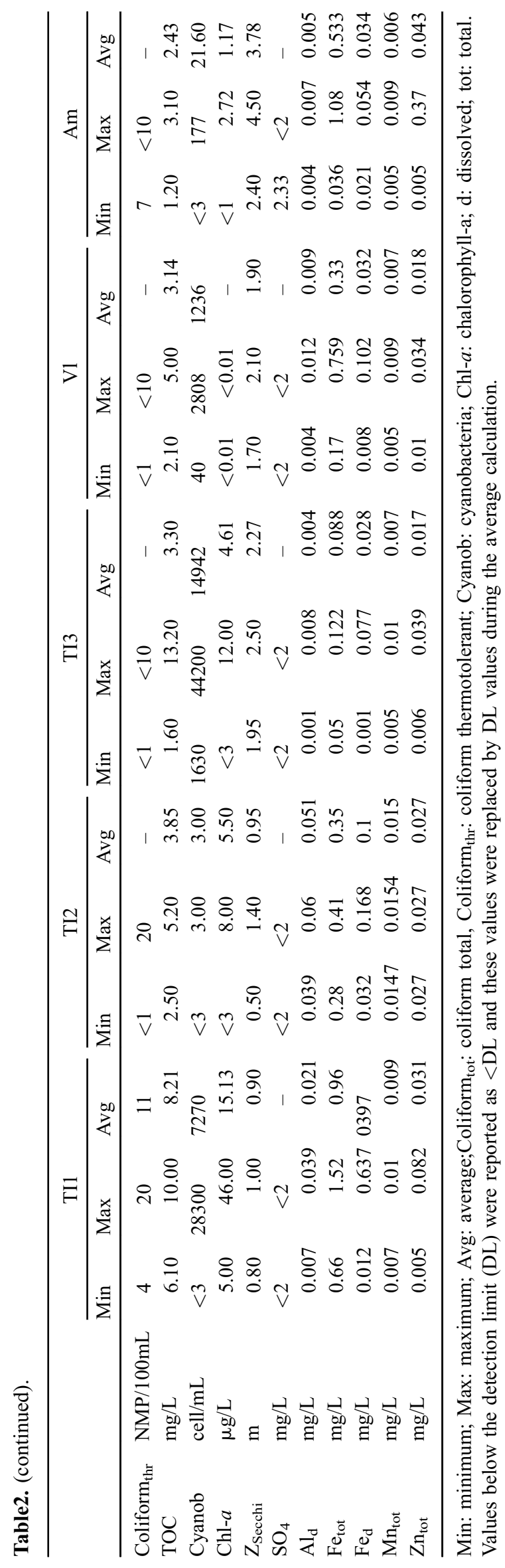

column; thus, a complete anoxia hypolimnion was not observed. Biological oxygen demand (BOD) is mostly $\leq 3 \mathrm{mg} / \mathrm{L}$ in all lakes, except a few exceptions.

The $\mathrm{pH}(3.6-7.2)$ was acidic to slightly alkaline in nature. Although the water $\mathrm{pH}$ was less varied between seasons, it was generally higher in the surface water and more acidic in nature towards the bottom (Fig. 4). According to Michigan Department of Environmental Quality (2013), the lakes were categorized as low to moderate $\mathrm{pH}$ and low alkalinity (as they have alkalinity $<2 \mathrm{mg} / \mathrm{L}$; Tab. 3), which indicates lesser buffering capacity and high degree of sensitivity to acid inputs (e.g. Taylor, 1984). EC was low in both periods, though higher values were recorded in the rainy period $(\mathrm{avg}, 8.1-14 \mu \mathrm{S} / \mathrm{cm})$. In general, the EC is not correlated with depth (Fig. 4), but, except few outliers, higher values were observed in shallowest lake, TI2. This may likely be caused by the increase of dissolved ions at the benthic zone due to more intense chemical activity. The EC values have a strong relation with TDS. Turbidity had low variation between seasonal periods, as well as along the vertical profile, but it was highly variable among lakes (Fig. 4). Higher values in TI1 and TI2 indicate that the presence of organic and inorganic suspended materials is favored in shallow lakes as they are more susceptible to wind action and high organic decomposition. Among the nutrient concentration in lakes, TP varied from $<10-150 \mu \mathrm{g} / \mathrm{L}$ to $<10$ $40 \mu \mathrm{g} / \mathrm{L}$ in the rainy and dry periods, respectively. Highest TP was found in Vl, but no conclusive seasonal and vertical trend was observed (Fig. 4). The total N, nitrate $\left(\mathrm{NO}_{3}\right)$ and ammonia $\left(\mathrm{NH}_{4}-\mathrm{N}\right)$ were low in all lakes, but a little higher values were observed in Vl lake. Total $\mathrm{N}$ concentration varied from 0.32 to $0.54 \mathrm{mg} / \mathrm{L}$ and the level of potential risk of eutrophication based on TN concentration is low to medium (Vollenweider, 1976; Cardoso et al., 2001). Total organic carbon (TOC) concentration was comparatively higher in the rainy season than in the dry season. The vertical distribution of TOC was relatively homogenous in all lakes, with highest concentration was in Tl1. Water hardness is attributed to presence of alkaline earth metals mainly $\mathrm{Mg}$ and $\mathrm{Ca}$ in solution. On the basis of total hardness $(<5 \mathrm{mg} / \mathrm{L}$ in all lakes), lake waters can be categorized as soft water (Tab. 3) following the guideline of Michigan Department of Environmental Quality (2013).

Heavy metals are another class of pollutants responsible for several heath diseases. This study analyzed the concentrations of $\mathrm{Al}, \mathrm{Ag}, \mathrm{Ba}, \mathrm{B}, \mathrm{Be}, \mathrm{Cd}, \mathrm{Cr}, \mathrm{Co}, \mathrm{V}, \mathrm{U}, \mathrm{Pb}, \mathrm{Cu}, \mathrm{Fe}, \mathrm{Mn}$, $\mathrm{Ni}, \mathrm{Si}, \mathrm{Se}, \mathrm{Hg}$, and $\mathrm{Zn}$ in the collected water samples, where only $\mathrm{Fe}, \mathrm{Al}, \mathrm{Mn}$, and $\mathrm{Zn}$ were detected, while other were below detection limit, thus they are not presented in Table 2. The concentrations of $\mathrm{Fe}(\mathrm{t})$ and $\mathrm{Fe}(\mathrm{d})$ showed mixed patterns with respect to seasons, but varied between lakes, highest concentrations were measured for Tl1. Along the profile, $\mathrm{Fe}$ (t) concentrations were comparatively lower at the surface than bottom.

The water transparency $\left(Z_{\text {Secchi }}\right)$ varied widely between lakes. It was lowest for TI2 and highest was for Am (Tab. 2). Comparing different seasons, $Z_{\text {Secchi }}$ was lower during the dry period. Chl- $a$ concentrations ranged from $<1$ to $38 \mu \mathrm{g} / \mathrm{L}$ in the rainy period and from $<1$ to $46 \mu \mathrm{g} / \mathrm{L}$ in the dry period. The highest values in both periods were observed at Vl and Tl1, whereas Tl2 and Am have presented the lowest values (Tab. 2). Cyanobacteria was also higher in the dry period and varied from $<3$ to 44200 cell $/ \mathrm{mL}$ while in the rainy period varied 

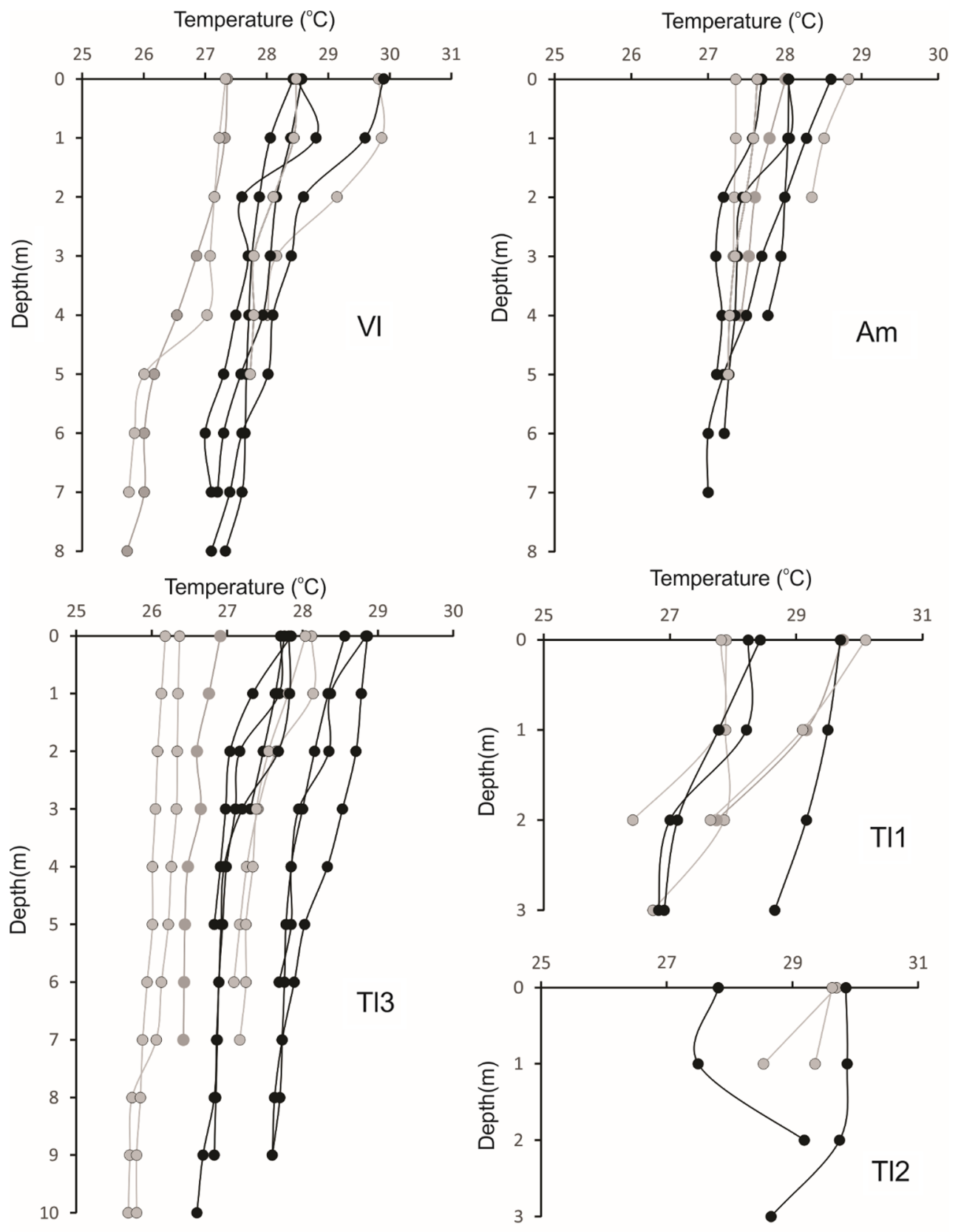

- Dry Period

$\longrightarrow$ Rainy Period

Fig. 3. Vertical temperature profile in all lakes during the dry and rainy seasons.

from $<3$ to $7821 \mathrm{cel} / \mathrm{mL}$; lower concentrations were recorded for TI2 and Am in both periods. Both Chl-a and cyanobacteria show weak distribution pattern along the vertical profile (Fig. 4).

Table 4 presents the CONAMA classification of various parameters based on average concentrations in the studied lakes. This indicates the concentrations of DO, turbidity, and Chl- $a$, except for TI1 Lake, and cyanobacteria conform to Class $\mathrm{I}$ and $\mathrm{II}$ in both periods. Concentrations of $\mathrm{Cl}^{-}, \mathrm{NO}_{3}^{-1}$, $\mathrm{NO}_{2}^{-}, \mathrm{SO}_{4}^{2-}$ dissolved $\mathrm{Al}$, dissolved $\mathrm{Fe}$, total $\mathrm{Mn}$ and total $\mathrm{Zn}$ conform to Classes I and II in both periods, except for TI1 Lake, where dissolved Fe concentration may conform to Class
III. Regarding the E. coli (coliform thermotolerant) content (Tab. 4), Carajás lakes are classified as Class I according to CONAMA Resolution 357 (Brasil, 2005). Furthermore, the number of faecal coliform or E. coli in Carajás lakes did not exceed $10 \mathrm{NMP} / 100 \mathrm{~mL}$ and based on this most of the waters of the Carajás lakes are considered as suitable for swimming and fishing according to EPA (2009), but not for drinking purpose as it shows low to intermediate risk following WHO (1997).

The WQI values are ranging from 74 to 80 (TI1), 72 to 78 (TI2), 67 to 81 (TI3), 71 to 92 (VI) and 71 to 86 (Am) in the rainy season and 73 to 78 (TI1), 73 to 75 (TI2), 68 to 82 (TI3), 

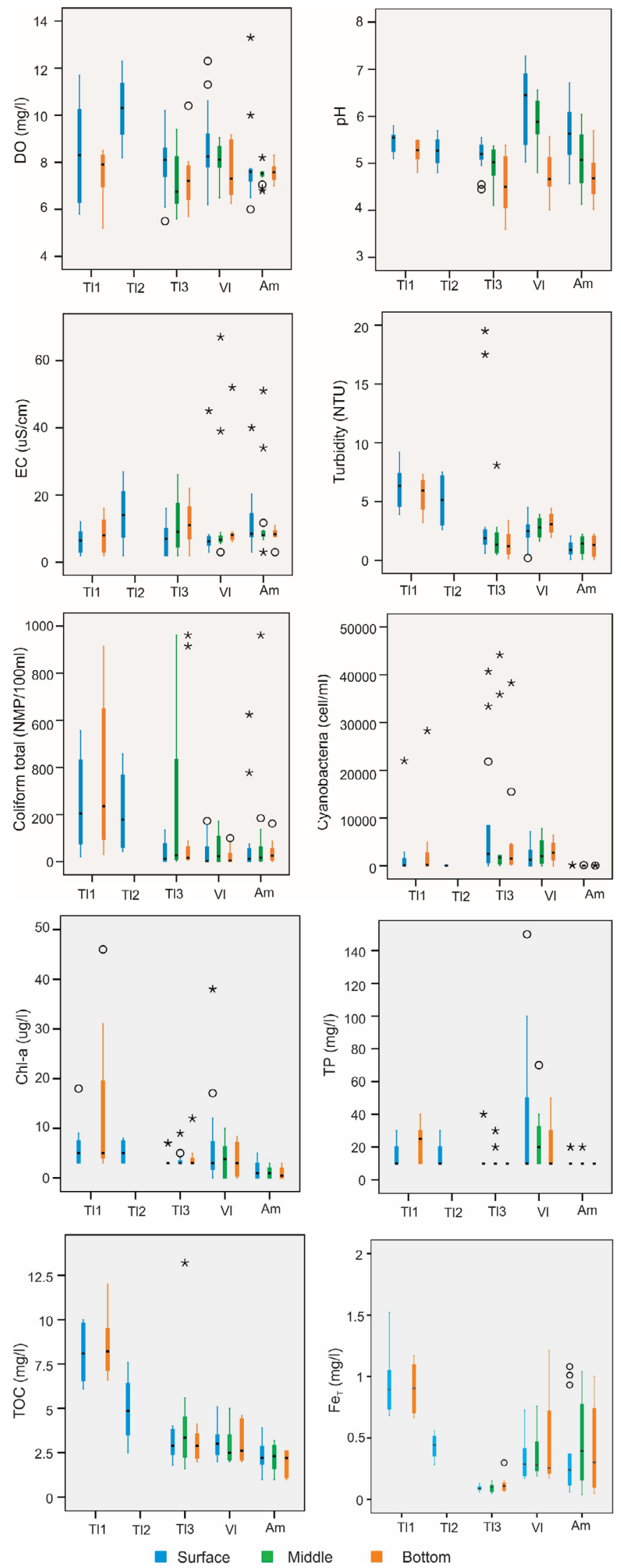

Fig. 4. Box plot showing the vertical distribution (surface, middle, bottom) of water quality parameters in the studied 5 lakes.
71 to $92(\mathrm{Vl})$ and 66 to $90(\mathrm{Am})$ in the dry period (Fig. 5). This indicates most water samples were classified as good to excellent quality in both periods. The TSI of all lakes in both dry and rainy season are presented in Figure 6. V1, TI1 and TI2 showed a broad range of trophic conditions and can be classified as oligotrophic to eutrophic. TI3 was classified into oligotrophic state and Am was classified as ultra-oligotrophic to slightly oligotrophic. TI1 and TI2 show higher trophic state during the dry period, while Vl shows higher trophic state during the rainy season.

PCA results of water quality parameters for both periods have been given in Figure 7, which shows factor loading of principal components (eigenvector $>1$ ) along with their cumulative variance $(\%)$. This extracted three principal components which accounted for the majority of the variance. The first two main factors of PCA showed significant associations of different variants. In rainy period (Fig. 7), the first component (PC1) explained $33 \%$ and $\mathrm{PC} 2$ represented $21.7 \%$ of the total variance. Both PC1 and PC2 shows high positive loading of Chl- $a$, TP and cyanobacteria, while total coliform, E. coli, $\mathrm{NO}_{3}$ and $\mathrm{NH}_{4}$ and temperature were associated negatively with $\mathrm{PC} 1$ and positively with $\mathrm{PC} 2$, but only Secchi was associated negatively with both PC1 and PC2. This association clearly shared almost all lakes, except lake $\mathrm{Am}$. Also, in this season the TI lakes tended to group together, and the $\mathrm{Vl}$ and $\mathrm{Am}$ became more prominent. In dry period (Fig. 7), PC1 and PC2 are accounted for $35.4 \%$ and $19.7 \%$ of the total variance, respectively, and only Secchi showed high positive loading in PC1. Cyanobacteria, Chl- $a, \mathrm{NO}_{3}$ and $\mathrm{NH}_{4}$ were negatively loaded in both $\mathrm{PC} 1$ and $\mathrm{PC} 2$ while total coliform, temperature, TP and E. coli were positively loaded in PC2. This also indicates some similarity between all lakes other than Am. In this period, part of the samples of the Am were grouped with the $\mathrm{Vl}$ and TI3 but this was not so prominent in the rainy season.

\subsection{Plankton community}

A total of 51 zooplankton and 102 phytoplankton taxa were collected during the period of sampling. For the zooplankton community, rotifers were the richest group with 28 taxa, followed by cladocerans (17 taxa) and copepods (6 taxa) (Tab. S1). The genus Polyarthra, Diaphanosoma and Notodiaptomus were the most abundant and frequent all over the study. For the phytoplankton community, the groups Zygnemaphyceae, Cyanophyceae and Chlorophyceae were the richest ones with 28,24 , and 22 taxa, respectively (Tab. S1). Regarding species richness, zooplankton was highest in $\mathrm{Vl}$, whereas phytoplankton was highest in TI1. In general, the species richness for both group of organisms was higher mainly in the dry season (Fig. 8). For the zooplankton, the highest species richness was observed in $\mathrm{Vl}$ (23 species, Fig. 8) while in the phytoplankton community the highest richness was recorded in the TI1 (35 taxa, Fig. 8C). The highest densities were observed in the rainy season for both zooplankton and phytoplankton communities (Fig. 8). The highest total density for phytoplankton was $4.3 \times 10^{5}$ individu$\mathrm{als} / \mathrm{m}^{3}$ in TI1 and for zooplankton was $4.7 \times 10^{5}$ individuals $/ \mathrm{m}^{3}$ also in TI1 (Figs. 8D and 8B, respectively). The environments from Serra dos Carajás showed some peculiarities in their zooplankton and phytoplankton community composition 
P.K. Sahoo et al.: Ann. Limnol. - Int. J. Lim. 53 (2017) 467-483

Table 3. Level of pH, alkalinity, and hardness in water collected from Carajás upland lakes and their classification.

\begin{tabular}{|c|c|c|c|c|c|c|}
\hline Lakes & \multicolumn{2}{|r|}{$\mathrm{pH}$} & \multicolumn{2}{|c|}{ Alkalinity } & \multicolumn{2}{|l|}{ Hardness } \\
\hline V1 & $4-7.3$ & Low-moderate & $<2$ (low) & high & $<5$ & soft \\
\hline $\mathrm{Am}$ & $4-6.7$ & Low-moderate & $<2$ (low) & high & $<5$ & soft \\
\hline TI1 & $4.8-6.2$ & Low & $<2$ (low) & high & $<5$ & soft \\
\hline TI2 & $4.8-5.7$ & Low & $<2$ (low) & high & $<5$ & soft \\
\hline
\end{tabular}

${ }^{*} \mathrm{pH}$ : low $(<6.5)$; moderate $(6.5-9)$; high $(>9)$; total alkalinity $\left(\mathrm{mg} / \mathrm{L}\right.$ as $\left.\mathrm{CaCO}_{3}\right)$ : low $(<23)$; moderate $(23-148)$; high $(>148)($ Michigan Department of Environmental Quality, 2013).

${ }^{* *}$ Levels of hardness $\left(\mathrm{mg} / \mathrm{L} \mathrm{CaCO}_{3}\right)$ : soft (0-60); moderate (61-120); hard (121-180); very hard (>180) (Michigan Department of Environmental Quality, 2013).

${ }^{* * *}$ Sensitivity of lakes acid rain (Taylor, 1984) based on alkalinity (mg/l as $\left.\mathrm{CaCO}_{3}\right)$ : high (0-2); moderate (2-10); low (10-25); nonsensitivity $(>25)$.

(Fig. 9). The zooplankton from TI2 and TI3 tended to be more similar between them, compounding a group separated of the others lakes, independent of the season and the type of data (abundance or presence/absence) (Fig. 9A and C).

\section{Discussion}

\subsection{Water quality assessment}

In accordance with the physical, chemical and microbiological characteristics of water obtained during the studied period, it was confirmed that lake waters from the Carajás region are of good quality and the average concentrations of most of the parameters, except few exceptions, were within the limit of class I and II freshwaters proposed in Brazilian environmental law (Brasil, 2005), and this assessment was less varied between seasonal climatic periods.

\subsection{Limnological characteristics and their controlling factors}

The decrease of Secchi depth (water transparency) in the dry period is mainly due to reduction of water depth. However, variation of Secchi depth between lakes is likely caused by various factors such as phytoplankton biomass, morphological features of lakes, catchment soil erosion and internal lake processes such as resuspension and diffusion (Hakanson, 2005). Phytoplankton biomass has an inverse relationship with water transparency (Chellappa et al., 2009b; Cunha and Calijuri, 2011), and this relationship was clearly established in Am lake, where higher Secchi is related to lower phytoplankton biomass. On the other hand, lower Secchi depth in TI1 and TI2 is highly influenced by the morphological features of lakes, mainly shallower depth. This may be the cause for high TOC and turbidity in TI2 and TI1, as the shallow depth leads to more decomposition of organic matters in sediments and thereby increase of suspended particles at the benthic zone. Therefore, morphometric factors are important for identifying water body types related to water quality (Moses et al., 2011; Stefanidis and Papastergiadou, 2012).

Water temperature slightly differed between rainy and dry seasons, but comparatively higher temperature in TI1 and TI2 could be attributed to the very shallow bottom exposed to direct sunlight. Furthermore, though water temperature varied between surface and bottom of the lake, the maximum difference was $\leq 2{ }^{\circ} \mathrm{C}$ (with few exceptions). This indicates that these lakes were weakly stratified in both seasons and, in some cases, they are relatively homogenous and a thermocline is indistinct. This is mainly influenced by morphometric characteristics, mainly shallow depth which favored mixing processes by wind action, besides other factors such as air temperature, high precipitation, and convention mixing (Podsetchine and Schernewski, 1999; Sahoo et al., 2016). Similar studies are reported from Kashmir valley lakes (Kaul, 1977).

In lentic freshwater ecosystems, patterns of thermal stratification play an important role in controlling the vertical distribution of nutrients and DO (Ezekiel et al., 2015; Sahoo et al., 2016). In this study, weak thermal stratification possibly caused vertical mixing (from surface to bottom zones) of DO and nutrients (mainly TP) in the water column and absence of anoxia hypolimnic zone in all lakes. Nevertheless, higher DO content in the surface layer is possibly due to more photosynthetic activities and/or the diffusion of atmospheric oxygen by wind action (Downing and Truesdale, 1995) and lower hypolimnetic oxygen could be due to decomposition of organic matter by aerobic bacteria in bottom sediments. Weak thermal structure of waters may also be the cause of vertical mixing of biological parameters such as Chl-a, cyanobacteria and coliform, as it controls the distribution of DO and TP in water columns. Although, sediments play an important role in sediment-water nutrient exchanges, low concentrations of TP in bottom water may have influenced by sediment organic matter, redox conditions, and various Fe-oxyhydroxide minerals, which potentially affected the strength of ionic phosphorus sorption to sediment surfaces (Wetzel, 2001).

The principal water bodies are found to be acidic and this can be explained by the absence of base and by the ferruginous lateritic nature of catchment. This may have caused lower alkalinity and lesser buffering capacity of water bodies. On the other hand, it leads to high degree of sensitivity to acid inputs (e.g. Taylor, 1984). More acidic $\mathrm{pH}$ towards bottom may be attributed to the higher bacterial decomposition of sedimentary organic carbon which releases $\mathrm{CO}_{2}$ and $\mathrm{H}_{2} \mathrm{~S}$ that make the 
Table 4. Lake water classification based on the average concentrations of water quality parameters provided in Table 1 in relations to CONAMA Resolution 357 (Brasil, 2005).

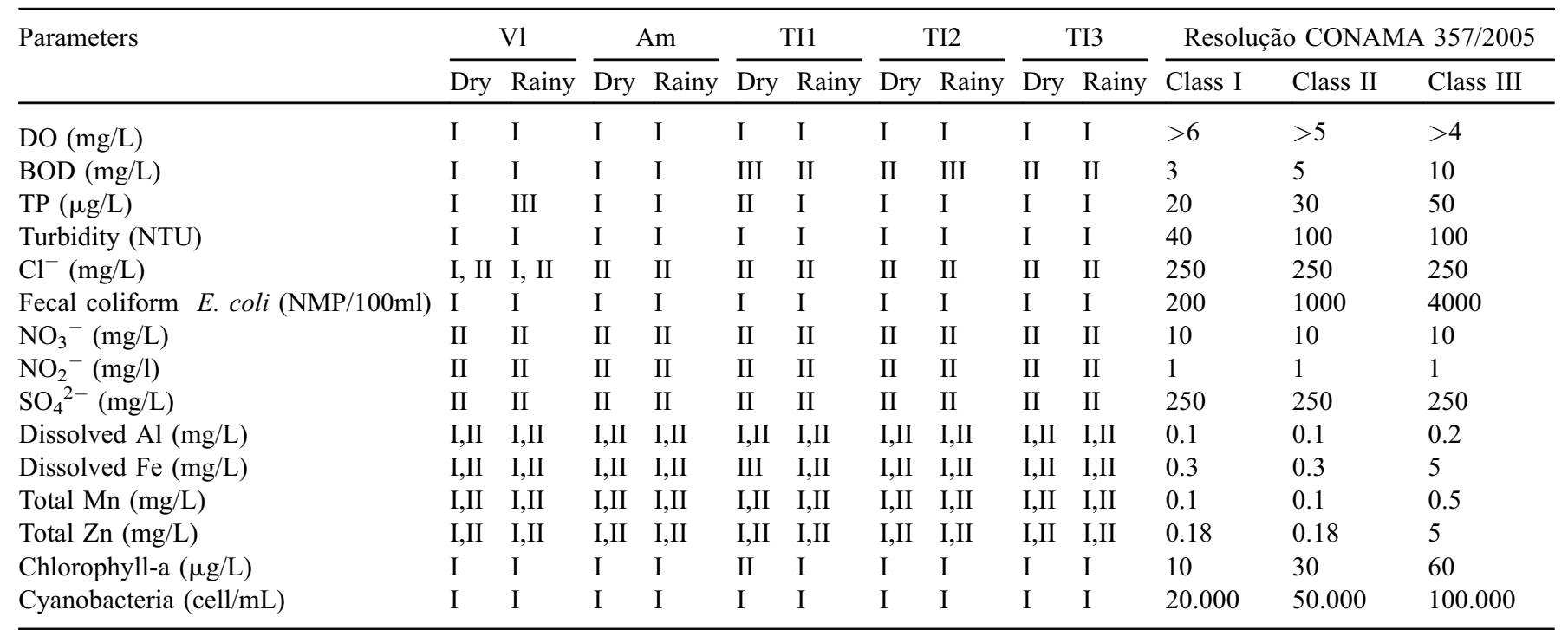

E. coli (Escherichia coli) is determined as coliform thermotolerant. Class I: These waters that can be designed to supply for consumption human (after simplified treatment); Class II designed to supply for human consumption (after treatment conventional); Class III: water that can be designed to supply for consumption human (after conventional or advanced treatment).

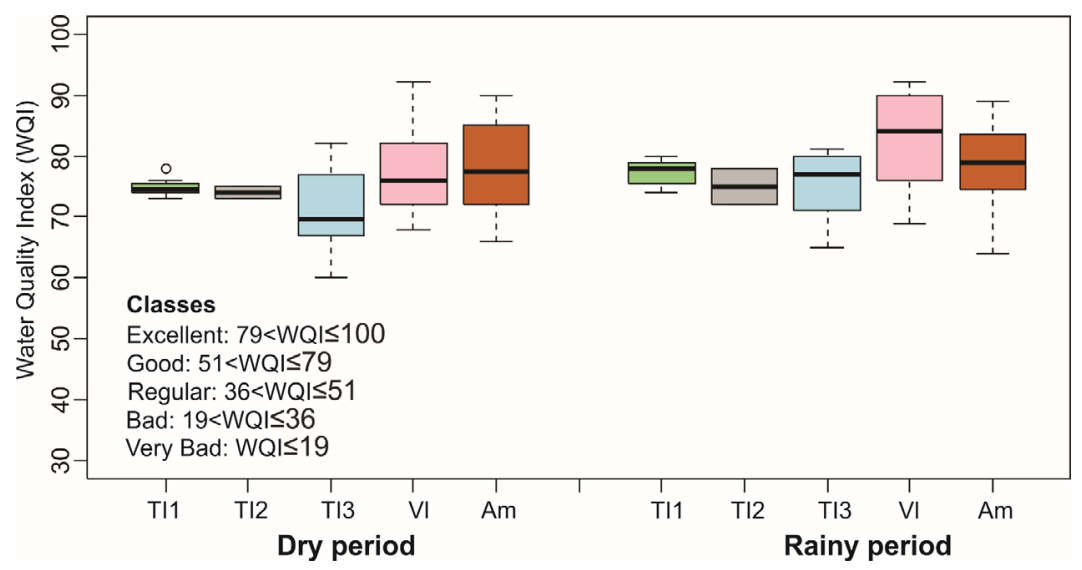

Fig. 5. Variation of Water Quality Index (WQI) in both periods of Violão, Amendoim, Três Irmãs lakes.

water acidic (Wetzel, 1983). Nevertheless, the higher values of $\mathrm{pH}$ at the surface associated with higher temperatures may be due to higher photosynthetic activity, which decreases $\mathrm{CO}_{2}$ assimilation (Sahoo et al., 2016). Decomposition of organic matter in sediments also leads to reduce $\mathrm{Fe}^{3+}$ to $\mathrm{Fe}^{2+}$, which has strong ability to diffuse to overlying water. This may be caused high concentrations of $\mathrm{Fe}$ in bottom waters.

In most lake waters, the total concentrations of major cations such as $\mathrm{Ca}, \mathrm{Mg}, \mathrm{Na}$, and $\mathrm{K}$ are equal to the sum of the concentrations of $\mathrm{Cl}^{-}, \mathrm{SO}_{4}{ }^{2-}$ and $\mathrm{HCO}_{3}{ }^{-}$. Exceptions to this are the studied water containing high concentrations of other cations, e.g. Fe. Low contents of $\mathrm{Ca}$ and $\mathrm{Mg}$ and high contents of Fe in lake waters may be explained by the dominance of Ferich laterite and absence of carbonate rocks in the catchment areas. This also caused very low total salt contents (i.e., avg. $\mathrm{EC}<15 \mu \mathrm{S} / \mathrm{cm}$ ) and low alkalinity, as well as very low concentrations of heavy metals in waters. Therefore, there is a close correspondence between the rock substrate in the catchment and metal contents in water ( $c f$. also Camarero et al., 2009; Ramos et al., 2016). Anions usually comprise more diverse sources than cations. The capture of atmospheric $\mathrm{CO}_{2}$ during rock weathering provides bicarbonate, and atmospheric deposition brings $\mathrm{Cl}^{-}$and $\mathrm{SO}_{4}{ }^{2-}$, although the main source of the latter is usually rock weathering (Camarero et al., 2009). Low content of these ions in waters could also be due to geological control.

Although WQI indicates high similarity among the studied lakes regarding their water quality (good to excellent categories), the trophic state of these lakes varied substantially from ultra-oligotrophic to eutrophic states. This is in general controlled by nutrient contents mainly TN and TP (Cardoso et al., 2001; Sahoo et al., 2016), thus these concentrations were 


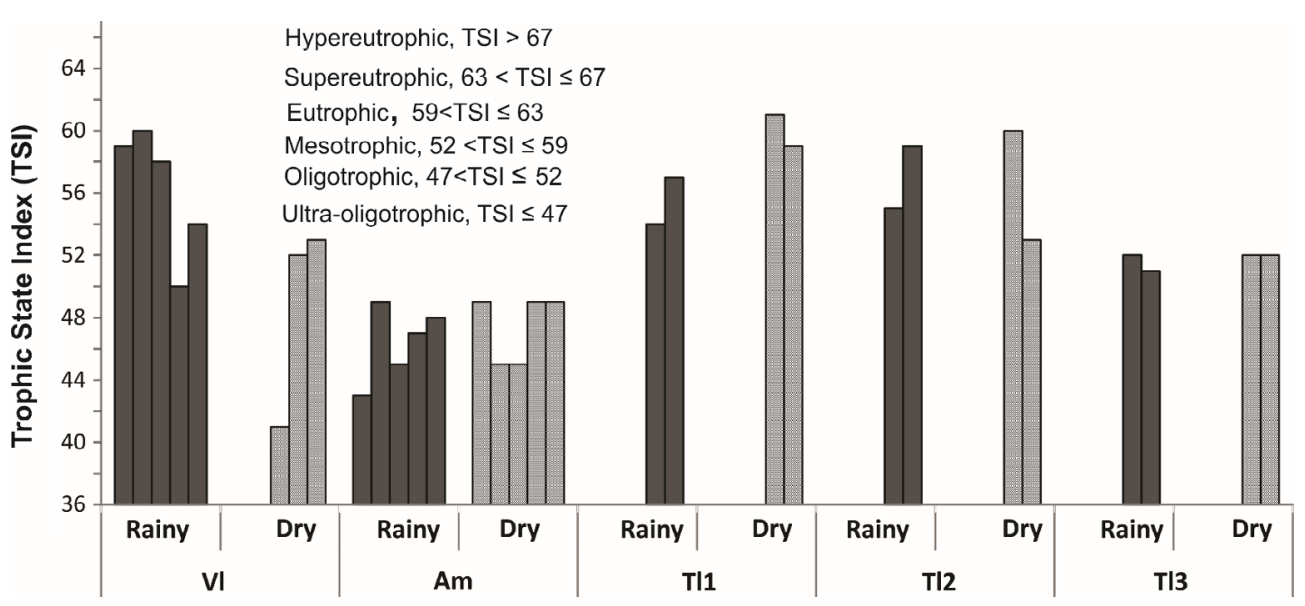

Fig. 6. Trophic state of studied lakes during both dry and rainy seasons. Each solid bar indicates one sampling period between 2013 and 2016. TSI is calculated based on the average concentrations of patameters in each sampling period.
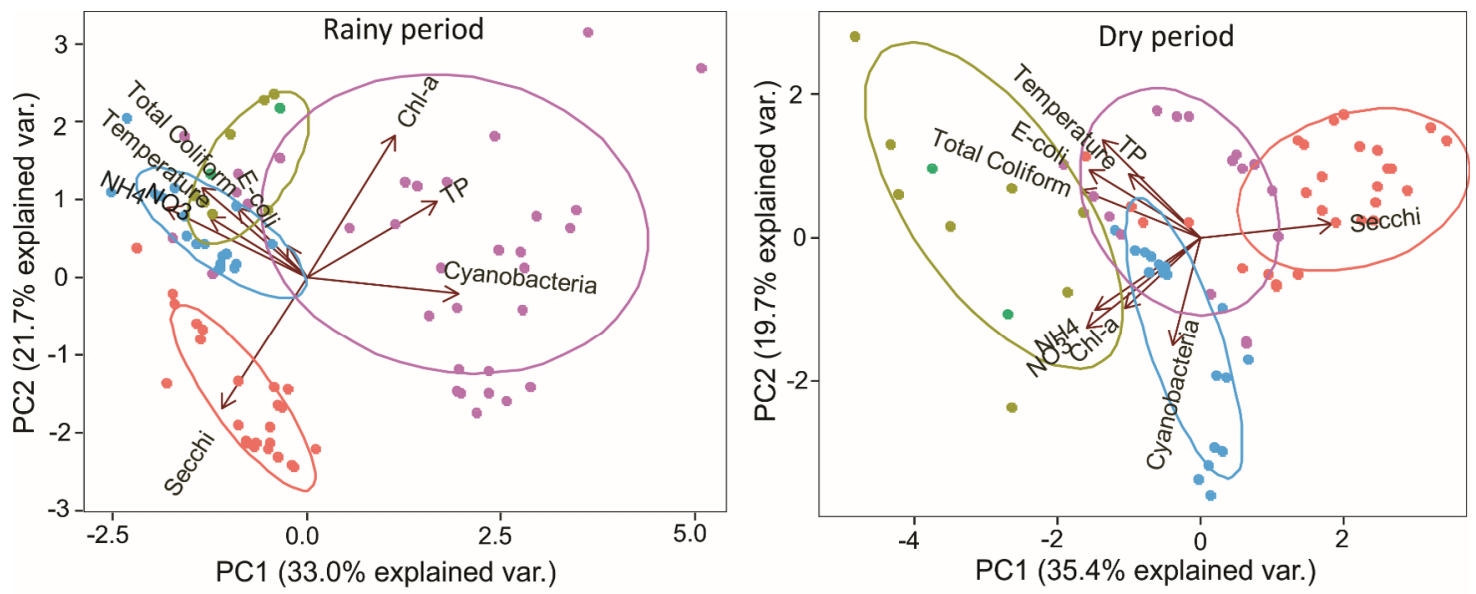

$\rightarrow \mathrm{Vl} \rightarrow \mathrm{Am} \rightarrow \mathrm{Tl} 1 \rightarrow \mathrm{Tl} 2 \rightarrow \mathrm{Tl} 3$

Fig. 7. Principal Component Analysis of limnological parameters studied during both dry and rainy seasons from all five lakes. Grouping of lakes was based on the environmental variables such as Temperature, TP, Chl- $a, \mathrm{NO}_{3}, \mathrm{NH}_{4}$, Coliform, Cyanobacteria and $\mathrm{Z}_{\mathrm{Secchi}}$.

used as a proxy to evaluate the potential risk to lake eutrophication. In the studied lakes, the TN concentrations indicating low to medium risk of eutrophication (Vollenweider, 1976; Cardoso et al., 2001). Regarding, TP content, Vollenweider (1976) suggests a TP concentration of only $30 \mu \mathrm{g} / \mathrm{L}$ as the lower limit necessary to promote excessive algal growth and eutrophic conditions. Using this value as reference, the TP content in Vl and TI1 may promote algal growth and this may be the cause of higher trophic nature of these lakes. In addition, morphological feature, such as shallow depth which causes lower Secchi depth, is also a potential factor for high eutrophic conditions, this is observed in TI1 and TI2.

In the PCA analysis, Am lake shows different behavior when compared to V1, TI1 and TI3, in both periods, due to low content of TP, Chl- $a$ and cyanobacteria. This variability may be due to different catchment characteristics which control nutrients levels, as the latter lakes have locally mafic/Al-enriched soils in their catchment while the former lake presents mostly lateritic crust, which is less susceptible to chemical weathering. Furthermore, in the case of V1 lake, P-enrichment could be caused by the presence of guano in the caves and margins of the catchment through leaching or erosional transport. This is possibly the reason of the association of Chl- $a$ with TP observed in rainy period. However, this explanation is not valid for the dry period as these variables are poorly correlated, indicating TP was probably not the only limiting factor for lake productivity. Similarly, the poor correlation between Chl- $a$ and $\mathrm{NO}_{3}$ and $\mathrm{NH}_{4}$ also indicates that multiple factors control their abundance. Alcântara et al. (2011) discussed several environmental factors such as water level, surface temperature, turbidity and mixing process, which can influence the nutrient availability, can control the Chl-a concentrations. Light conditions could be an additional factor to this because increase of light conditions facilitate algal production, which subsequently increases Chl- $a$ concentrations. This is possibly the reason of comparatively high Chl- $a$ contents in TI lakes. Although many studies have shown that the increase in abundance of cyanobacteria can be attributed to nutrient enrichment, such as TP and TN (Chellappa et al., 2009b; Wojciechowski and Padial, 2015), in this study these variables are poorly correlated. A recent study in Peri Lake (Santa Catarina 

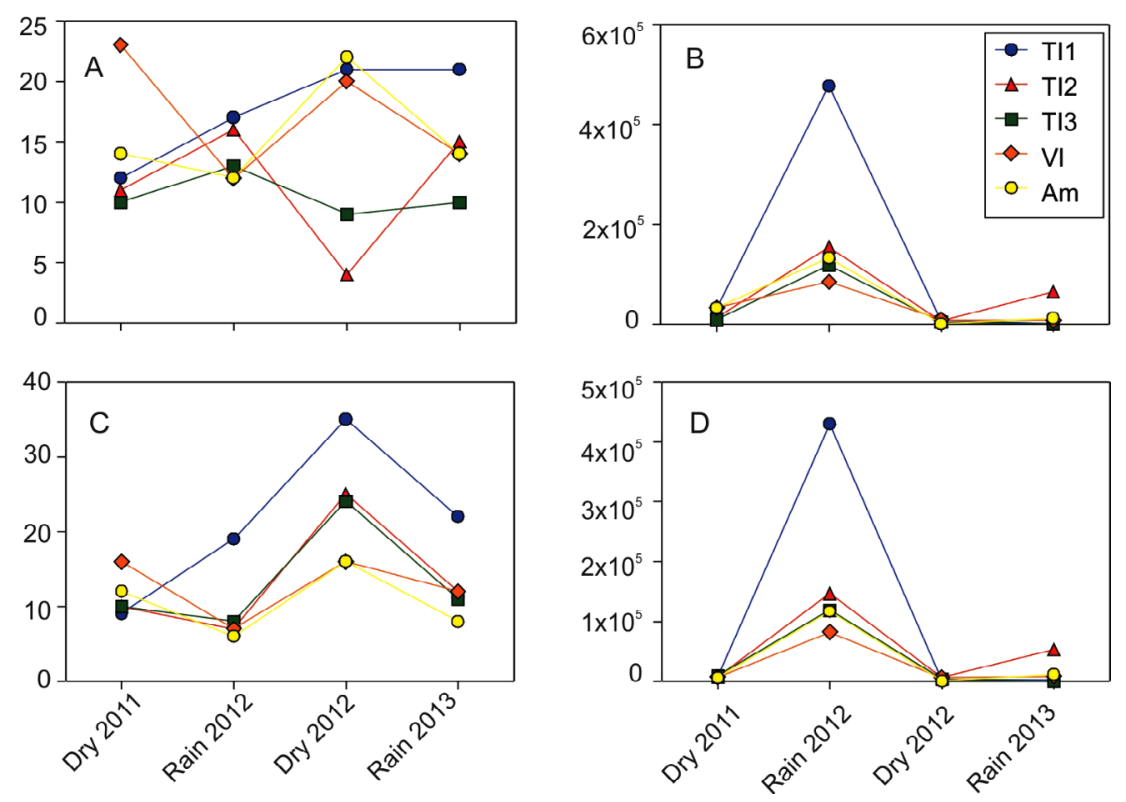

Fig. 8. Species richness and abundance of zooplankton (A and B) and phytoplankton (C and D) community in all the lakes between 2011 and 2013

Island, Brazil) has also reported that cyanobacteria can dominate even in low nutrient conditions for long periods (Tonetta et al., 2015). This can be due to other factors such as light conditions and morphology of lakes (Dokulil and Teubner, 2000). Morphological features such as shallow depth are responsible for turbid water by basin flushing and frequent re-suspension of organic matter particles from the sediment, which influence the density of plankton population. This possibly acted as a stress factor to reduce the relative abundance of cyanobacteria in TI1 and TI2. Moreover, seasonal influence can be one of the important factors controlling this, as lower content of cyanobacteria in the rainy period, except few exceptions, can be explained by the instability or mixing of the water columns in this period, due to frequent rainfall events (Dantas et al., 2008). This was also observed in previous studies conducted in eutrophic reservoirs in Brazil (Cunha and Calijuri, 2011; Dantas et al., 2008; Costa et al., 2009). Poor associations of E. coli and total coliform with TP and nitrogen compounds during both dry and rainy seasons indicate that these biological variables may have mixed influence in their abundance.

\subsection{Plankton community and controlling factors}

The plankton community is considered a good indicator of changes in aquatic environment because they include different groups with different life history traits, dispersal abilities and short reproductive processes, which allow them to have a rapid response (Cáceres and Soluk, 2002; Calijuri et al., 2002; Frisch et al., 2012; Silva et al., 2013). In the present study, rotifers were the richest among the zooplankton community. This dominance of rotifers has also been observed in several studies in Brazilian lakes, wherein rotifers were more speciose than microcrustaceans (Robertson and Hardy, 1984; Bozelli, 1992; Rocha et al., 1995; Neves et al., 2003; Lopes et al., 2014). Similarly, the genus
Polyarthra, Diaphanosoma and Notodiaptomus which were most abundant and frequent in all over the study are typically recorded and dominant in amazon ecosystems (Bozelli, 1992; Previattelli et al., 2013; Brito et al., 2015).

Regarding phytoplankton community, the groups Zygnemaphyceae, Cyanophyceae and Chlorophyceae are frequent and abundant in the Amazon basin and they have been registered in several studies in the area (Huszar and Reynolds, 1997; Melo and Huszar, 2000; Souza and Melo, 2011; Cunha et al., 2013). In the Carajás region the phytoplankton community was characterized by small chroococcales (Synechocystis spp. and Synechococcus spp.) with genus typical of clear and oligotrophic lakes; and chlorococcales (Scenedesmus spp.) and desmids (Closterium sp.; Cosmarium sp.) together with filamentous algae (Lyngbya putealis), more commonly observed in the dry seasons.

Plankton community varied widely among lakes. The highest richness phytoplankton community in the TI1 is probably due to the decrease of water level, which results in the concentration of nutrients and it triggers off increase in phytoplankton production and consequently zooplankton productivity (Melo and Huszar, 2000; Okogwu, 2010). Moreover, in the dry season, there is more concentration of individuals in the water column which increases the probability of sampling rare species. However, some species such as Bosminospis deitersi (Cladoceran) were observed mostly in the rainy season. This fact can be associated to the enlargement of the habitat of this phase, which minimizes the interspecific competition (Hardy, 1980; Rocha et al., 1995).

Seasonal and spatial influence is also evident on both zooplankton and phytoplankton communities, which were abundant in rainy seasons and in TI1 Lake. This antagonistic relation between species richness and abundance regarding the seasonality may be related to the dominance of some species in the rainy season because of the lack of food or decrease of 

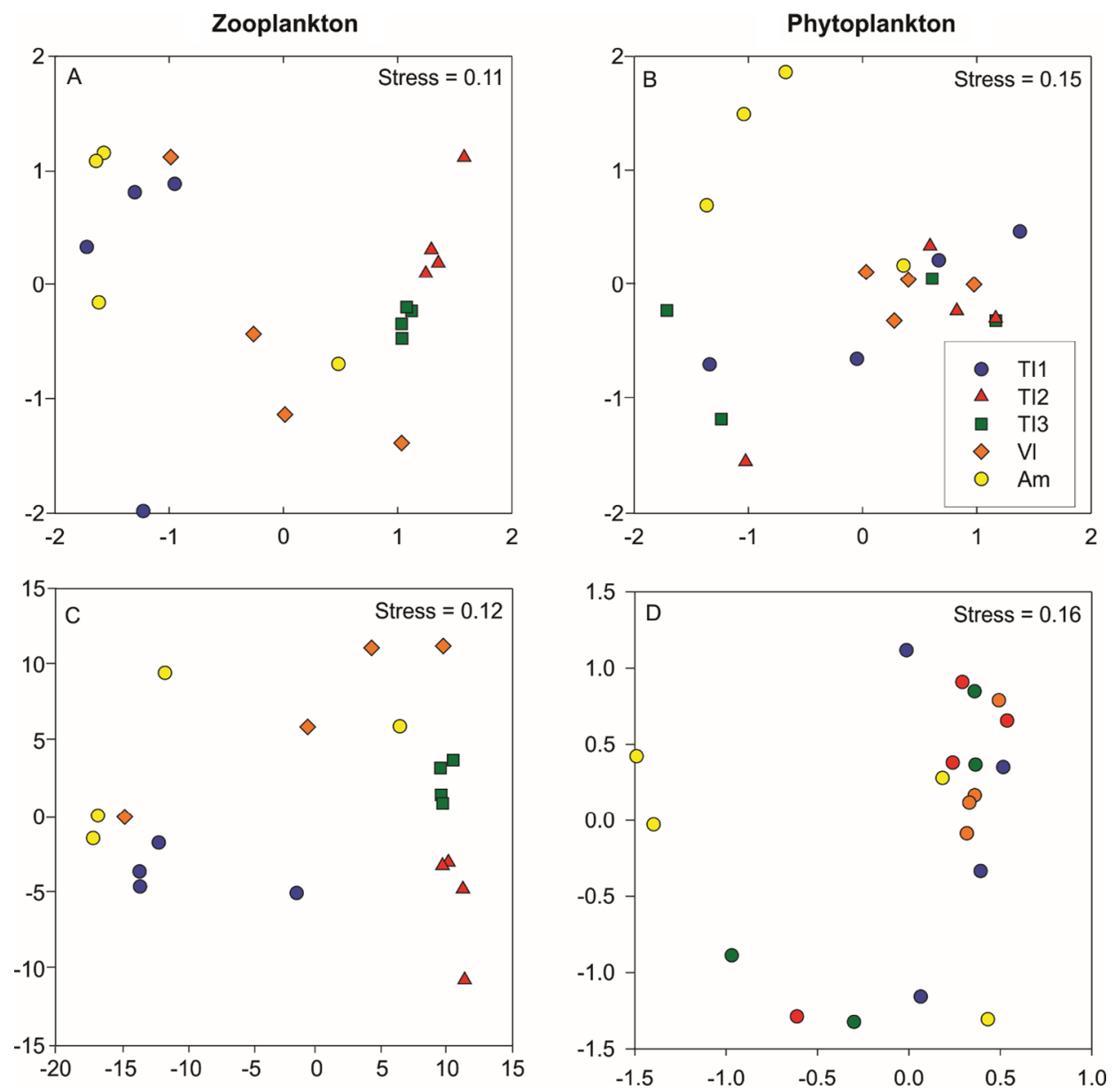

Fig. 9. NMS of the zooplankton and phytoplankton community of all the systems studied, for abundance (A and B) and presence and absence (C and D) data using a Bray-Curtis and Jaccard Index.

pressure of predation and competition. In fact, some species such as Polyarthra dolichoptera (rotifer) and Synechocystis aquatilis (Cyanophyceae) that occur throughout the studied lakes have peak abundances in the rainy season when compared to the dry season. These species are considered cosmopolitans and have tolerance to a wide environmental gradient (Domingos et al., 1994; Melo and Huszar, 2000; Obertegger et al., 2014), such as high DO values and low nutrients content, characteristics observed in our environments in the rainy season. Although high values of DO can favor the development of plankton community, the lack of food due the low nutrient content contributes to the species depression in this season. For some cyanobacterias, such as Synechocystis, which can grow rapidly (C-strategists) can become dominant in periods of high water since they are the morphological types which are better adapted to this kind of environment (Melo and Huszar, 2000). Besides that, cyanobacterias are in general considered an inadequate food for zooplankton which favors their growth (Arcifa et al., 1994).

The lakes from Serra dos Carajás showed some peculiarities. The TI lakes use to be connected in the rainy season, and this can contribute for the higher similarity between them. In the other hand, the Vl, and TI1 also tend to be more similar, even without connection. The same pattern was observed for the phytoplankton community, wherein all the lakes have not showed a clear spatial distribution. This result may suggest that the distance among the different lakes may not have been sufficient to create dispersal barriers for these groups. Some authors suggest that single-celled organisms, such as algae, may have higher dispersal rates due to their small size, and spatial factors may have little influence on community structuring (Finlay et al., 1996; Hillebrand et al., 2001).

Moreover, the phyto and zooplankton, besides their small sizes, can produce dormant stages (cysts and resting eggs) capable to resist to several environmental conditions and are able to be transported by different vectors such a wind, water and animals, favoring the dispersal (Incagnone et al., 2015). Some studies have shown that zooplankton organisms can effectively disperse in distances as high as $100 \mathrm{~km}$ (Shurin, 2000), suggesting the inexistence of real dispersal barriers (Cohen and Shurin, 2003; Havel and Shurin, 2004; Louette and De Meester, 2005; Vanschoenwinkel et al., 2008). In this study, since the major distance among the lakes was not over $10 \mathrm{~km}$, the absence of dispersal limitation among these groups can be considered.

\section{Conclusions}

The results obtained during this study indicated that the Carajás upland lakes are shallow and weakly stratified (classified as polymictic type), which controlled vertical mixing of limnological parameters and absence of anoxia 
hypolimnic zone in all lakes. Water quality was "good" and the parameters were mostly in compliance with class I and II of the Brazilian legislation (CONAMA Resolution $\left.n^{\circ} 357 / 05\right)$. Seasonal variation of water quality was very small, except for biological parameters. High concentrations of total $\mathrm{Fe}$ and very low concentrations of other metal ions in water is due to the catchment lithology which mainly composed of ferruginous laterite. Trophic state index (TSI) varies significantly among the lakes, with lakes Am and TI3 are showing oligotrophic and higher TSI values are corresponding to Vl, TI1 and TI2. PCA results indicate that these lakes differ in their limnological parameters, with lower values of TP, Chl- $a$ and cyanobacteria in Am lakes in contrast to other lakes; but TP is not solely controlling the phytoplankton biomass in these lakes. Nevertheless, limnological characteristics of lakes are highly influenced by lithological and morphological parameters. In general, the Carajás lakes were more oligotrophic compared to other lagoons in other regions of Brazil, presenting a small planktonic community and very similar between them, suggesting that physical distance was not an efficient dispersion barrier for them. This study outcome contributes to understand the common limnological processes in Amazonian upland lakes. In addition, this work can give valuable insight for developing a lake index system for the conservation and preservation of lakes in the Carajás area.

\section{Supplementary Material}

Supplementary tables.

The Supplementary Material is available at http://www. limnology-journal.org/10.1051/limn/2017026/olm.

Acknowledgements. This study has been funded by Vale Institute of Technology and CNPq (479182/2012-4; 442088/ 2014-0). The second (JTFG), third (PWMSF) and last (RD) authors were supported by CNPq through research scholarship (302839/2016-0, 306450/2013-5, and 306108/2014-3, respectively). Authors are also thankful to the members of DIPF, GELIF, DIST, LISF, LAMSF of Vale S.A. for field support and scientific discussions. This project was carried out in the National Forest of Carajás under permission of IBAMA (SISBIO 35594-2).

\section{References}

ABNT. 1987. NBR 9898:1987-Preservação e técnicas de amostragem de efluentes líquidos e corpos receptores.

Alcântara E, Novo EM, Stech J, Barbosa CF, Bonnet MP, Stech J, Ometto JP. 2011. Environmental factors associated with long-term changes in chlorophyll-a concentration in the Amazon floodplain. Biogeosci Discuss 8: 3770-2011.

Alvares CA, Stape JL, Sentelhas PC, Gonçalves JLM, Sparovek G. 2014. Köppen's climate classification map for Brazil. Meteorol Z 22: 711-728.

Arcifa MS, Castilho MSM, Carmouze JP. 1994. Composition et évolution du zooplancton dans une lagune tropicale (Brésil) au cours d'une période marquée par une mortalité de poissons. Rev Hydrobiol Trop 27: 251-263.

Bozelli RL. 1992. Composition of the zooplankton community of Batata and Mussurá lakes and of the Trombetas River, State of Pará, Brasil. Amazoniana 12: 239-261.
Brasil. 2005. Ministério do Desenvolvimento Urbano e Meio Ambiente. Conselho Nacional do Meio Ambiente -CONAMA. 2005. Resolução $n^{\circ}$ 357, de 17 de março de 2005. Dispõe sobre a classificação dos corpos de água e diretrizes ambientais para o seu enquadramento, bem como estabelece as condições e padrões de lançamento de efluentes, e dá outras providências Diário Oficial da República Federativa do Brasil, Brasília, DF, 18 March. 2005.

Brito SAC, Camargo M, Melo NFAC, Estupiñan RA. 2015. A checklist for the zooplankton of the Middle Xingu - an Amazon River system. Braz J Biol 75: S55-S64.

Brown RM, Mcclelland NI, Deininger RA, Tozer RG. 1970. A water quality index: do we dare? Water Sew Works 117: 339-343.

Buraschi E, Salerno F, Monguzzi C, Barbiero G, Tartari G. 2005. Characterization of the Italian lake-type and identification of their reference site using anthropogenic pressure factors. J Limnol 64: 75-84.

Burden DG, Malone RF. 1987. A classification of freshwater Louisiana lakes based on water quality and user perception data. Environ Monit Assess 9: 197-193.

Busch WDN, Sly PG. (Eds.) 1992. The development of an aquatic habitat classification system for lakes. Boca Raton, FL: CRC Press, $240 \mathrm{p}$.

Cáceres CE, Soluk DA. 2002. Blowing in the wind: a field test of overland dispersal and colonization by aquatic invertebrates. Oecologia 131: 402-408.

Calijuri MC, Santos ACA, Jati S. 2002. Temporal changes in the phytoplankton community structure in a tropical and eutrophic reservoir (barra Bonita, S.P. -Brazil). J Plankton Res 24: 617-634.

Camarero L, Rogora M, Mosello R, Anderson NJ, Barbieri A, Botev I et al. 2009. Regionalisation of chemical variability in European mountain lakes. Freshw Biol 54: 2452-2469.

Cardoso AC, Duchemin J, Magoarou P, Premazzi G. 2001. Criteria for the identification of freshwaters subject to eutrophication: their use for the implementation of the nitrates and urban waste water treatment directives. EUR Report 19810 EN. Luxembourg: European Commission Joint Research Centre.

Carlson RE. 1977. A trophic state index for lakes. Limnol Oceanogr 22: 361-369.

Catalan J, Rondón JCD. 2016. Perspective for an integrated understanding of tropical and temperate high-mountain lakes. $J$ Limnol 75: 215-234.

CETESB. 2006. Dispõe sobre a homologação da revisão da Norma Técnica L5.303 - Fitoplâncton de Água Doce - Métodos Qualitativo e Quantitativo (Método de Ensaio) - dez/2005. Companhia de Tecnologia de Saneamento Ambiental, Secretária de Meio Ambiente, Estado de São Paulo. (http://www.bmn.com.br/ plan-leg/ma/est-sp/decis/cetesb42-06.pdf). Accessed on 11/05/2015.

Chellapa NT, Câmara FRA, Rocha O. 2009a. Phytoplankton community: indicator of water quality in the Armando Ribeiro Gonçalves Reservoir and Pataxó Channel, Rio Grande do Norte, Brazil. Braz J Biol 69: 241-251.

Chellappa NT, Chellappa T, Camara FRA, Rocha O, Chellappa S. $2009 \mathrm{~b}$. Impact of stress and disturbance factors on the phytoplankton communities in northeastern Brazil reservoir. Limnologica 39: 273-282.

Cohen GM, Shurin JB. 2003. Scale-dependence and mechanisms of dispersal in freshwater zooplankton. Oikos 103: 603-617.

Companhia de Tecnologia de Saneamento Ambiental (CETESB), (2004, 2005 and 2006). Relatório 57 de Qualidade das Águas Interiores do Estado de São Paulo, São Paulo.

Costa IAS, Cunha SRSC, Panosso R, Araújo MFF, Melo JLS, Eskinazi Sant'anna EM. 2009. Dinâmica de cianobactérias em reservatórios eutróficos do semi-árido do Rio Grande do Norte. Oecol Bras 13: 382-401. 
Cunha DGF, Calijuri MC. 2011. Variação sazonal dos grupos funcionais fitoplanctônicos em braços de um reservatório tropical de usos múltiplos no estado de São Paulo (Brasil). Acta Bot Bras 25: 822-831.

Cunha EDS, Cunha AC, Silveira Jr AM, Faustino SMM. 2013. Phytoplankton of two rivers in the eastern Amazon: characterization of biodiversity and new occurrences. Acta Bot Bras 27: 364-377.

Dantas EW, Moura AN, Bittencourt-Oliveira MC, Arruda-Neto JDT, Cavalcanti ADC. 2008. Temporal variation of the phytoplankton community at short sampling intervals in the Mundaú reservoir, Northeastern Brazil. Acta Bot Bras 22: 970-982.

Diehl S, Berger S, Ptacnik R, Wild A. 2002. Phytoplankton, light and nutrients in a gradient of mixing depths: field experiments. Ecology 83: 399-411.

Dokulil MT, Teubner K. 2000. Cyanobacterial dominance in lakes. Hydrobiologia 438: 1-12.

Domingos P, Huszar VLM, Carmouze JPC. 1994. Composition et biomasse du phytoplancton d'une lagune tropicale (Brésil) au cours d'une période marquée par une mortalité de poissons. in : la lagune de la barra (Brésil) : Causes et conséquences d'une mortalité de poissons. Rev Hydrobiole Trop 27: 235-250.

Downing AL, Turesdate Z. 1995. Some factors affecting rate of solution of oxygen in water. $J$ Appl Chem 5: 570.

Elmoor-Loureiro LMA. 1997. Manual de identificação de cladóceros límnicos do Brasil, Universa, Brasília, 156 p.

EPA 2004. Method 9060A - Total organic carbon. 5P. Revision 1. United States Environmental Protection Agency.

U.S. Environmental Protection Agency. 2009. Water Quality Standards http://www.epa.gov/waterscience/standards/wqslibrary/az/ az9wqs.pdf.

Eskinazi-Sant'Anna EM, Menezes R, Xosta IS, Araújo M, Panosso R, Attayde JL. 2013. Zooplankton assesmblages in eutrophic reservoirs of the Brazilian semi-arid. Braz J Biol 73: 37-52.

Ezekiel Y, Tukur AL, Mubi AM. 2015. Morphometric characteristics of selected fluviatile lakes in the Upper benue Valley area of Adamawa state, Northeastern Nigeria. J Geogr Reg Plann 8: 56-64.

Finlay BJ, Esteban GF, Fenchel T. 1996. Global diversity and body size. Nature 386: 132-133.

Fonseca BM, Bicudo CEM. 2008. Phytoplankton seasonal variation in a shallow stratified eutrophic reservoir (Garças Pond, Brazil). Hydrobiologia 600: 267-282.

Frisch D, Cottenie K, Badosa A, Green A. 2012. Strong spatial influence on colonization rates in a pioneer zooplankton metacommunity. PLoS One 7: 1-10.

Golder. 2010. Anexo IV - Geologia. Estudo de Impacto Ambiental, EIA Projeto Ferro Carajás S11D.

Gomes EAT, Godinho MJL. 2003. Structure of the protozooplankton community in a tropical shallow and eutrophic lake in Brazil. Acta Oecol 24: S153-S161.

Guimarães JTF, Souza-Filho PWM, Alves R, Souza EB, Costa FR, Reis LS et al., 2014. Source and distribution of pollen and spores in surface sediments of a plateau lake in southeastern Amazonia. Quat Int 26: 181-196.

Guimarães JTF, Rodrigues TMR, Reis LS, De Figueiredo MMJC, Da Silva DF, Alves R, Giannini TC, Carreira LMM, Dias ACR, Silva EF, Sahoo PK, Silva MS, Souza-filho PWM. (2017) Modern pollen rain as a background for palaeoenvironmental studies in the Serra dos Carajás, southeastern Amazonia. Holocene 27: 1055-1066.

Gunkel G. 2000. Limnology of an equatorial high mountain lake in Eucador, Lago San Pablo. Limnologica 30: 113-120.

Hakanson 2005. The important of lake morphology and catchment characteristics in limnology - ranking based on statistical analysis. Hydrobiologia 541: 117-137.

Häkanson L, Jansson M. 1983. Principles of lake sedimentology. Heidelberg: Springer Verlag, 316 p.
Hardy ER. 1980. Composição do zooplâncton em cinco lagos da Amazônia Central. Acta Amaz Manaus 10: 557-609.

Havel JE, Shurin J.B. 2004. Mechanisms, effects, and scales of dispersal in freshwater zooplankton. Limnol Oceanogr 49: 1229-1238.

Hillebrand H, Watermann F, Karez R, Berninger UG. 2001. Differences in species richness patterns between unicellular and multicellular organisms. Oecologia 126: 114-124.

Hundey EJ, Russell SD, Longstaffe FJ, Moser KA. 2016. Agriculture causes nitrate fertilization of remote alpine lakes. Nat Commun 7: 10571.

Huszar VLM, Reynolds CS. 1997. Phytoplankton periodicity and sequences of dominance in an amazonian flood-plain lake (Lago Batata, Pará, Brasil): response to gradual environment change. Hydrobiologia 346: 169-181.

Huszar VLM, Silva LHS, Marinho M, Domingos Sant'Anna P. 2000. Cyanoprokaryote assemblages in eight productive tropical Brazilian Waters. Hydrobiologia 424: 67-77.

Hutchinson GE, Löffler H. 1956. The thermal classification of lakes. Proc Natl Acad Sci Washington 42: 84-86.

Incagnone G, Marrone F, Robba L, Barone R, NaselliFlores L. 2015. How do freshwater organisms cross the "dry ocean"? A review on passive dispersal and colonization processes with a special focus on temporary ponds. Hydrobiologia 750: 103-123.

Kaul V. 1977. Limnological survey of Kashmir lakes with reference to trophic status and conservation. Int J Ecol Environ Sci 3: 29-44.

Koste W. 1978. Die Radertiere Mitteleuropas begrundet von Max Voigt. Stuttgart: Gebruder Borntraeger, 673 p.

Lamparelli MC. 2004. Degrees of trophy in water bodies of São Paulo: Evaluation of monitoring methods. Doctoral Thesis, Institute of Biosciences, University of São Paulo, São Paulo.

Lewis WMJr. 1987. Tropical limnology. Ann Rev Ecol Syst 18: 159184.

Livingstone DA. 2003. Global climate change strikes a tropical lake. Science 301: 468-469.

Lopes PM, Bini LM, Declerck SAJ, Farjalla VF, Vieira LCG, Bonecker CC, Lansac-Tôha FA, Esteves FA, Bozelli RL. 2014. Correlates of zooplankton beta diversity in tropical lake systems. PLoS One 9: E109581.

Lopes PM, Caliman A, Carneiro LS, Bini LM, Esteves FA, et al. 2011. Concordance among assemblages of upland Amazonian lakes and the structuring role of spatial and environmental factors. Ecol Indic 11: 1171-1176.

Louette G. De Meester L. 2005. High dispersal capacity of cladoceran zooplankton in newly founded communities. Ecology 86: 353-359.

Lund JWH, Kipling C, Lecren ED. 1958. The inverted microscope method of estimating algal number and the statistical basis of estimating by counting. Hydrobiologia 11: 143-170.

Margaritora FG, Bazzanti M, Ferrara O, Mastrantuono L, Seminara M, Vagaggini D. 2003. Classification of the ecological status of volcanic lakes in Central Italy. J Limnol 62: 49-59.

Maurity CW, Kotschoubey B. 1995. Evolução recente da cobertura de alteração no platô N1- Serra dos Carajás-PA: Degradação, pseudocarstificação, espeleotemas. Boletim do Museu Paraense Emilio Goeldi. Série Ciênc da Terra 7: 331-362.

Mazumder A, Taylor WD, McQueen DJ, Lean DRS. 1990. Effects of fish and plankton on lake temperature and mixing depth. Science 247: 312-315.

Melo S, Huszar VLM. 2000. Phytoplankton in an Amazonian floodplain lake (Lago Batata, Brasil): diel variation and species strategies. J Plankton Res 22: 63-76.

Molisani MM, Barroso HS, Becker H, Moreira MOP, Hijo CAG, Monte TM, et al. 2010. Trophic state, phytoplankton assemblages and limnological diagnosis of the Castanhão Reservoir, CE, Brazil. Acta Limnol Bras 22: 1-12. 
Moraes BC, Costa JMN, Costa ACLM, Costa MH. 2005. Variação espacial e temporal da precipitação no estado do Pará. Acta Amaz 35: 207-214.

Morais MC, Martins PPM, Paradella WR. 2011. Mapping ironmineralized laterite environments based on textural attributes from MAPSAR image simulation - SAR R99B (SIVAM/SIPAM) in the Amazon Region. Rev Bras Geof 29: 99-111.

Moses SA, Janaki L, Joseph S, Justus J, Vimala SR. 2011. Influence of lake morphology on water quality. Environ Monit Assess 182: 443-454.

Neves IF, Rocha O, Roche KF, Pinto AA. 2003. Zooplankton community structure of two marginal lakes of the river cuiabá (Mato Grosso, Brazil) with analysis of rotifera and cladocera diversity. Braz J Biol 63: 329-343.

Obertegger U, Flaim G, Fontaneto D. 2014. Cryptic diversity within the rotifer Polyarthra dolichoptera along an altitudinal gradient. Freshw Biol 59: 2413-2427.

Okogwu OI. 2010. Seasonal variations of species composition and abundance of zooplankton in Ehoma Lake, a floodplain lake in Nigeria. Rev Biol Trop 58: 171-182.

Osborne PL. Eutrophication of Shallow tropical lakes. In O'Sullivan PE, Reynolds CS eds The Lakes Handbook, Volume 2: Lake Restoration and Rehabilitation, Oxford, UK: Blackwell Science Ltd, 2004.

Paradella WR, Ferretti A, Mura et al. 2015. Mapping surface deformation in open pit iron mines of Carajás Province (Amazon Region) using an integrated SAR analysis. Eng Geol 193: 61-78.

Pasztaleniec A, Poniewozik M. 2010. Phytoplankton based assessment of the ecological status of four shallow lakes (Eastern Poland) according to Water Framework Directive - a comparison of approaches. Limnologica 40: 251-259.

Petrucio MM, Barbosa FAR, Furtado ALS. 2006. Bacterioplankton and phytoplankton production in seven lakes in the Middle Rio Doce basin, South-east Brazil. Limnologica 36: 192-203.

Previattelli D, PerbicheiNeves G, Santos-Silva En. 2013. Diaptomidae records (Crustacea: Copepoda: Calanoida: Diaptomidae) in the Newotropical region. Check List 9: 700-713.

Podsetchine V, Schernewski G. 1999. The influence of spatial wind in homogeneity on flow patterns in a small lake. Water Res 33: 3348-3356.

R Core Team 2012. R: A language and environment for statistical computing. Vienna, Austria: R Foundation for Statistical Computing. ISBN 3-900051-07-0, http://www.R-project.org/.

Ramos SM, Vaz APMS, Gusti DA, Filho EFR. 2016. Relationship between geological domain and physicochemical parameters in lotic system. Braz J Water Res 21: 882-893.

Reynolds CS, Huszar V, Kruk C, Naselli-Flores L, Melo S. 2002. Towards a functional classification of the freshwater phytoplankton. J Plankton Res 24: 417-428.

Robertson BA, Hardy ER. Zooplankton of amazonian lakes and rivers. In: Sioli H, ed. The amazon - limnology and landscape, ecology of a mighty tropical river and its basin. Netherlands: W. Junk Publishers, 1984. pp. 337-352.

Rocha O, Sendacz S, Matsumura-Tundisi T. 1995. Composition, biomass and productivity of zooplankton in natural lakes and reservoirs in Brazil. In: Tundisi JG, Bicudo CEM \& MatsumuraTundisi T eds, Rio De Janeiro: Limnology in Brazil. ABC/SBL, pp. 151-166.

Rowan JS, Soutar I, Philips GE. 2006. Morphometric analysis of UK lake systems as a compliance tool for the European water framework directive. Sediment Dyn Hydromorphology Fluv Sys. In: Proceedings of a symposium held in Dundee, UK: IAHS Publ.

Sahoo PK, Souza-Filho PWM, Guimarães JTF, Silva MS, Costa FR, Manes CLO, Oti D, et al. 2015. A multi-proxy geochemical study of surface sediments in a plateau lake of Carajás in the southeastern Amazon region: implication for provenance and post depositional processes. Appl Geochem 52: 130-146.

Sahoo PK, Guimarães JTF, Souza-Filho PWM, Silva MS, Silva Júnior RO, Pessim G, et al. 2016. Influence of seasonal variation on the hydro-biogeochemical characteristics of two upland lakes in the Southeastern Amazon, Brazil. An Acad Bras Cienc 88: 2211-2227.

Sawane AP, Puranik PG, Bhate AM. 2006. Impact of industrial pollution on river Irai, district Chandrapur with reference to fluctuation in $\mathrm{CO}_{2}$ and pH. Aquat Biol 21: 105-110.

Shurin JB. 2000. Dispersal limitation, invasion resistance, and the structure of pond zooplankton communities. Ecology 81:3074-3086.

Silva AQ, Paradella WR, Freitas CC, Oliveira CG. 2009. Relationship between PALSAR backscatter and surface-roughness parameters from iron laterites in Carajás, Amazon region. IEEE Trans Geosci Remote Sens 47: 4027-4031.

Silva IG, Moura AN, Dantas EW. 2013. Phytoplankton community of Reis lake in the Brazilian Amazon. An Acad Bras Cienc 85: 649-663.

Skowron R. 2009. Criteria of thermal classification of lakes. Bull Geogr Phys Geogr Ser 2: 89-105.

SMEWW. 2005. 1060-Collection and preservation of samples. Standard Methods for the Examination of Water and Wastewater.

Souza KF, Melo S. 2011. Levantamento taxonômico de desmídias (Chlorophyta) do Lago Novo (Amapá, Brasil): gêneros Staurastrum, Staurodesmus e Xanthidium. Acta Amaz 41: 335-346.

Stefanidis K, Papastergiadou E. 2012. Relationships between lake morphometry, water quality, and aquatic macrophytes, in greek lakes. Fresen Environ Bull 21: 10a.

Taylor JW. 1984. The Acid Test. Natural Resources Magazine, Wis Dept of Natural Resources, $40 \mathrm{p}$.

Tonetta D, Hennemann MC, Brentano DM, Petrucio MM. 2015. Considerations regarding the dominance of Cylindrospermopsis raciborskii under low light availability in a low phosphorus lake. Acta Bot Bras 29: 448-451.

Utermöhl H. 1958 Zur Vervollkommnung der quantitativen Phytoplankton-Methodik. Mitt Int Verein Theor Angew Limnol 9: 1-38.

Vanschoenwinkel B, Gielen S, Seaman M, Brendonck L. 2008. Any way the wind blows - frequent wind dispersal drives species sorting in ephemeral aquatic communities. Oikos 117: 125-134.

Vollenweider RA. 1976. Advances in defining critical loading levels for phosphorus in lake eutrophication. Mem Ist Ital Idrobiol 33: 53-83.

Wang M, Hou J, Lei Y. 2014. Classification of Tibetan lakes based on variations in seasonal lake water temperature. Chin Sci Bull 59: 4847-4855.

Wetzel RG. 1983. The oxygen content in freshwater. In: Brown M, ed. Limnology, p. 172.

Wetzel RG. 2001. The phosphorus cycle. Limnology: lake and river ecosystems, 3rd ed. San Diego: Acad. Press, 1006 p.

WHO. 1997. Guideline for drinking water quality, V-3. World Health Organization.

Wojciechowski J, Padial AA. 2015. Monitoring studies should consider temporal variability to reveal relations between cyanobacterial abundance and environmental variables. An Acad Bras Cienc 87: 1717-1726.

Cite this article as: Sahoo PK, Guimarães JTF, Souza-filho PWM, Bozelli RL, Araujo LRd, Menezes RdS, Lopes PM, Silva MSd, Rodrigues TM, Costa MFd, Dall'Agnol R. 2017. Limnological characteristics and planktonic diversity of five tropical upland lakes from Brazilian Amazon. Ann. Limnol. - Int. J. Lim. 53: 467-483 